Review Article

\title{
ETHNOBOTANICAL USES, PHYTOCHEMISTRY AND PHARMACOLOGICAL ACTIVITIES OF PEPEROMIA PELLUCIDA (L.) KUNTH (PIPERACEAE)-A REVIEW
}

\author{
RAGHAVENDRA H. L. ${ }^{1}$, PRASHITH KEKUDA T. R. ${ }^{*}$
}

${ }^{1}$ Department of Biochemistry, School of Medicine, Wollega University, Nekemte, Ethiopia, ${ }^{2}$ Department of Microbiology, S. R. N. M. N College of Applied Sciences, N. E. S Campus, Balraj Urs Road, Shivamogga 577201, Karnataka, India

Email: p.kekuda@gmail.com

Received: 02 Nov 2017 Revised and Accepted: 03 Jan 2018

\begin{abstract}
Peperomia pellucida (L.) Kunth is a herb belonging to the family Piperaceae. In this review, an extensive literature survey was carried out to compile information available on medicinal uses, phytochemistry and pharmacological properties of $P$. pellucida. The plant is used as food, flavoring agent and as medicine. The plant is used as medicine for treating various ailments or disorders such as asthma, rheumatism, wound, fever, stomach problems, kidney infection, hemorrhoid pain, joint pain, hypertension, diarrhea, snake bite and measles. The plant contains phytochemical groups such as alkaloids, flavonoids, saponins, terpenoids, steroids and glycosides. Compounds such as dill apiole, phytol, stigmasterol, sitosterol, secolignans, tetrahydrofuran lignans, highly methoxylated dihydronaphthalenone, peperomins, sesamin and isoswertisin have been identified in the plant. Studies have shown that the plant exhibited several pharmacological activities such as antimicrobial, antioxidant, anti-angiogenic, antiinflammatory, analgesic, antipyretic, neuropharmacological, antisickling, anticancer, enzyme inhibitory, antiulcer, hypotensive, immunostimulatory, fracture healing and antidiabetic activities which support the traditional use of the plant. Purified chemicals from the plant have also shown to exhibit certain pharmacological activities such as antiulcer, anticancer and antimicrobial activity. By this extensive literature review, it can be concluded that $P$. pellucida can be utilized as a promising candidate for developing newer drugs with potent pharmacological activities.
\end{abstract}

Keywords: Peperomia pellucida (L.) Kunth, Ethnomedicine, Traditional medicine, Phytochemical, Pharmacological activities

(C) 2018 The Authors. Published by Innovare Academic Sciences Pvt Ltd. This is an open access article under the CC BY license (http://creativecommons.org/licenses/by/4.0/) DOI: http://dx.doi.org/10.22159/ijpps.2018v10i2.23417

\section{INTRODUCTION}

Throughout the world, especially developing and under-developing countries, plants have been exploited as medicine to meet primary healthcare needs. It is estimated that vast majority of population relies on medicinal plants for therapy against several diseases or disorders. Traditional medicinal practitioners utilize plants, either singly or in certain formulations, to treat ailments. Non-availability (especially for people from remote areas) and high cost of modern drugs limits their use by people from economically poor background. Nowadays, medicinal plants are used routinely in urban settings in daily healthcare and as medication against ailments. Many indigenous medicinal systems such as Ayurveda, Siddha and Unani utilize several plant species. Besides, plants provide many lead compounds for the development of modern drugs. Majority of drugs available are from natural origin, especially from plants. Drugs such as taxol, quinine, artemisinin, vincristine, vinblastine, digoxin and codeine are from plant origin [1-6].

The genus Peperomia Ruiz and Pavon belongs to the family Piperaceae. The genus is the second largest genus in piperaceae and includes plants that are annual or perennial, usually succulent herbs and often epiphytic. The genus encompasses a number of species found distributed in tropical and subtropical regions worldwide. The species of Peperomia are characterized by bisexual flowers (sessile, sunk in rachis) in spike inflorescence and lateral or terminal stigma which is usually penicillate. The genus is often considered as one of the most species rich genera of angiosperms [7-10]. Peperomia pellucida (L.) Kunth (fig. 1) belonging to the family Piperaceae is commonly known by names such as pepper elder, rat ear and shining bush. The plant is native to South America and is found distributed in various countries in the world including India. The plant is very common during rainy season and usually grows in clumps in loose and humid soils and is found in shaded, damp habitats. The plant occurs more or less throughout year in wet places. It is characterized by succulent stems, fleshy and heart shaped leaves, and tiny dot like seeds attached to fruiting spikes. It is called neeru kaddi gida in Kannada. The plant is known to be edible and is considered to possess cooling property $[8,10,11]$. In the present review, we presented updated information (up to 2017) concerned with the ethnobotanical uses, phytochemical composition and pharmacological properties of $P$. pellucida. An extensive literature survey on various aspects of the plant was carried out by referring flora, journals, and various search engines including Google scholar, Science Direct and Pubmed.

\section{Plant description}

P. pellucida is a slender herb (reaching $30-50 \mathrm{~cm}$ in length) with straight and succulent stem and is cosmopolitan in distribution. Leaves are opposite and alternate, up to $2.5 \times 2 \mathrm{~cm}$, ovate-deltoid, obtuse to acute at apex. Leaves are thin, fleshy, smooth, membranous when dry, 5-7 nerved from the base. Petiole is up to $1.5 \mathrm{~cm}$ long. Spikes are terminal and leaf-opposed, up to $5 \mathrm{~cm}$ long. Flowering occurs more or less throughout year. Fruits are ribbed and reticulate, minute in size and almost dry $[8,10]$.

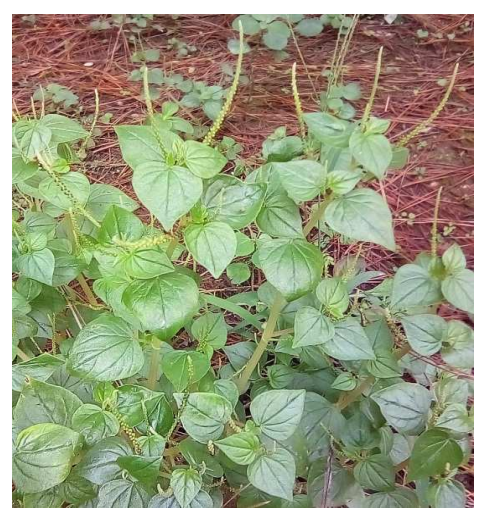

Fig. 1: Peperomia pellucida (L.) Kunth (photograph by prashith kekuda). 


\section{Ethnobotanical uses of $P$. Pellucida}

The plant $P$. pellucida is used ethno botanically as medicine, food and flavoring agent in various parts of the world. Aerial parts, young shoots, leaves and whole plant are used in the form of decoctions, juice, paste etc. to treat several diseases such as fever, cold, cough, viral diseases, rheumatic pain, asthma, vaginal infections and kidney infections. The Sumu (Ulwa) of southeastern Nicaragua and southern Miskitu uses $P$. pellucida against bites and stings (snakes, scorpions and insects), infections, venereal diseases and female disorders [12]. The plant is used as human food and medicine in Luang Prabang, Lao People's Democratic Republic [13]. In Lombok, Indonesia, the plant is used to treat fever [14]. In North-Kamrup district, Assam, India, the plant paste is applied externally to reduce pimple and white spots of the body [15]. In Trinidad and Tobago, the plant is use for cooling [16]. The whole plant is used in the treatment of measles in Ogun state, Nigeria [17]. Juice made from leaves and roots are used to treat athletes foot, decoction prepared from leaves is used in the treatment of hemorrhoid pain and kidney infection in Rondônia, Western Amazon, Brazil [18]. In Nigeria, the whole plant is used in haemmorhoids, hypertension, convulsion and bone fracture [19]. The whole plant is boiled and used to treat kidney infection and to lower hypertension in Mindanao, Philippines [20]. Table 1 depicts ethnobotanical (medicinal and non-medicinal) uses of $P$. pellucida in various parts of the world.

Table 1: Ethnobotanical uses of $P$. pellucida in various parts of the world

\begin{tabular}{|c|c|c|c|}
\hline Region & Part used & Uses & Reference \\
\hline Malappuram district, Kerala, India & Whole plant & $\begin{array}{l}\text { Decoction prepared from whole plant is taken internally for } \\
\text { treating rheumatism. }\end{array}$ & $\begin{array}{l}\text { Chithra and } \\
\text { Geetha [21] }\end{array}$ \\
\hline Barpeta district, Assam, India & $\begin{array}{l}\text { Plant juice, } \\
\text { leaf paste }\end{array}$ & $\begin{array}{l}\text { Plant juice is used in stomach problems, leaf paste is applied on } \\
\text { cuts and wounds. }\end{array}$ & Kalita et al. [22] \\
\hline East Sepik, Papua New Guinea & $\begin{array}{l}\text { Leaves, } \\
\text { whole plant }\end{array}$ & $\begin{array}{l}\text { Leaves are used as antidepressant and in the treatment of pimple. } \\
\text { Whole plant is used in the treatment of fever and headache. }\end{array}$ & Koch et al. [23] \\
\hline Indonesia & Aerial parts & Dizziness, headache, fever, stomachache & Waty et al. [24] \\
\hline Greater Khulna division, Bangladesh & Whole plant & Whole plant is used in the treatment of diarrhea. & $\begin{array}{l}\text { Rahmatullah et } \\
\text { al. [25] }\end{array}$ \\
\hline Bagerhat district, Bangladesh & - & Tribal community uses plant for medicinal purposes & Mollik et al. [26] \\
\hline Tinsukia district, Assam, India & Whole plant & $\begin{array}{l}\text { Paste made from the whole plant is applied on burns for quick } \\
\text { relief. }\end{array}$ & Buragohain [27] \\
\hline Assam, India & Young shoots & Young shoots are used as flavoring agents. & Bharali et al. [28] \\
\hline Morigaon district, Assam, India & Aerial parts & $\begin{array}{l}\text { Aerial part of the plant is used to treat stomach pain, joint pain and } \\
\text { headache. }\end{array}$ & $\begin{array}{l}\text { Bordoloi et al. } \\
\text { [29] }\end{array}$ \\
\hline Jalpaiguri district, West Bengal, India & Whole plant & Paste made from whole plant is used against boils. & Bose $[30]$ \\
\hline Kanda community, Bangladesh & Whole plant & $\begin{array}{l}\text { Paste made from the whole plant is applied by the sides of the } \\
\text { bitten place (poisonous snake, insect or reptile bites). }\end{array}$ & $\begin{array}{l}\text { Rahmatullah et } \\
\text { al. [31] }\end{array}$ \\
\hline Saramaccan Maroons in Suriname & Whole plant & $\begin{array}{l}\text { Used as herbal bath for children for general health promotion and } \\
\text { to get rid of evil. }\end{array}$ & $\begin{array}{l}\text { Ruysschaert et al. } \\
\text { [32] }\end{array}$ \\
\hline $\begin{array}{l}\text { Dominican Republic and New York city } \\
\text { (Dominican traditional medicine) }\end{array}$ & $\begin{array}{l}\text { Aerial parts, } \\
\text { leaf }\end{array}$ & $\begin{array}{l}\text { Aerial parts are used in the treatment of flu, leaves are used to } \\
\text { treat vaginal infections and asthma/chest congestion. }\end{array}$ & $\begin{array}{l}\text { Vandebroek et al. } \\
\text { [33] }\end{array}$ \\
\hline Okigwe Imo state, South Eastern Nigeria & Leaves & Leaves are used to treat athletes' foot and wound. & Uzodimma [34] \\
\hline Assam, India & $\begin{array}{l}\text { Leaf and } \\
\text { stem }\end{array}$ & Stem and leaves are used in urinary disorder and fever. & $\begin{array}{l}\text { Gogoi and Zaman } \\
\text { [35] }\end{array}$ \\
\hline Trinidad & Whole plant & $\begin{array}{l}\text { Infusion or decoction made from whole plant is used to treat cold } \\
\text { and cough and as cooling/cleansing agent. }\end{array}$ & Clement et al. \\
\hline Tshopo district, DR Congo & Leaves & Leaves are cooked and used as leafy vegetable. & $\begin{array}{l}\text { Termote et al. } \\
\text { [11] }\end{array}$ \\
\hline Moulvibazar district, Bangladesh & $\begin{array}{l}\text { Leaves, } \\
\text { whole plant }\end{array}$ & $\begin{array}{l}\text { Paste made from leaves and whole plant is used in the treatment } \\
\text { of fever in children and adults respectively. }\end{array}$ & Das et al. [37] \\
\hline Kamrup district, Assam, India & $\begin{array}{l}\text { Leaves and } \\
\text { stem }\end{array}$ & Leaves and stem are used in the treatment of fever. & $\begin{array}{l}\text { Bora and Das } \\
\text { [38] }\end{array}$ \\
\hline
\end{tabular}

Table 2: Phytochemical groups identified in P. pellucida

\begin{tabular}{lll}
\hline Plant part & Phytochemical group & Reference \\
\hline Whole plant & Tannins, saponins, flavonoids, terpenoids, phytosterols, alkaloids, phenolics & Gini and Jothi [46] \\
Leaf & Alkaloids, tannins, saponins, terpenoids, flavonoids, cardiac glycosides & Ojo et al. [47] \\
Leaf & Alkaloids, flavonoids, saponins, tannins, steroids, triterpenoids & Majumder and Kumar [48] \\
Leaf & Alkaloid, cardiac glycoside, terpene, saponin, tannin & Omotayo and Borokini [49] \\
Whole plant & Alkaloids, saponins, tannins, flavonoids, anthraquinones, glycosides & Idris et al. [50] \\
Leaf & Alkaloids, tannins, flavonoids, saponins and cardiac glycosides & Abere and Okpalaonyagu [51] \\
Leaf & Alkaloids, flavonoids & Ibibia [52] \\
Stem & Alkaloids, tannins, flavonoids, steroids, triterpenoids & Majumder [53] \\
Whole plant & Alkaloids, flavonoids, glycosides, saponins & Sheikh et al. [54] \\
Leaf & Alkaloids, tannins, saponins & Egwuche et al. [55] \\
Aerial parts & Alkaloids, flavonoid, tannins, saponins, steroids, glycosides & Raina and Hassan [56] \\
\hline
\end{tabular}

\section{Phytochemistry of P. Pellucida}

Plants produce a range of primary and secondary metabolites. The study of chemical compounds present in plants (phytochemicals) is known as phytochemistry. The therapeutic potential of plants is ascribed to the presence of a wide range of phytochemicals, mainly secondary metabolites. Significant advancements in the technology, mainly chromatographic and spectral analyses, led to the discovery of many types of phytochemicals from plants and the pharmacological studies revealed their potential role. Techniques 
such as column chromatography, Thin layer chromatography (TLC), Gas chromatography-mass spectrometry (GC-MS), Fouriertransform infrared spectroscopy (FT-IR) and Nuclear magnetic resonance (NMR) spectroscopic techniques are routinely used to identify phytochemicals present in plants [39-45]. Various researchers have identified phytochemical groups and chemical compounds in leaves and whole plant by standard phytochemical procedures and various analytical techniques.

Table 2 and 3 provides information on various phytochemical groups and chemicals identified in different parts of the plant by standard phytochemical tests and GC-MS analysis respectively.

Table 3: Chemical compounds identified in P. pellucida by GC-MS analysis

\begin{tabular}{|c|c|c|}
\hline Sample & Compounds identified & References \\
\hline Essential oil & Dillapiole, trans-caryophyllene & da Silva et al. [57] \\
\hline Leaf extract & phytol, 2-Naphthalenol, Hexadecanoic acid and 9,12-Octadecadienoic acid & Wei et al. [58] \\
\hline Essential oil & Dillapiole, myristicine & Francois et al. [59] \\
\hline Essential oil & $\begin{array}{l}\text { carotol, dill apiole, pygmaein, (E)-caryophyllene, germacrene } D, \beta \text {-elemene, camphor, daucene, } \\
\text { apiole, } \beta \text {-bisabolene and bicyclogermacrene }\end{array}$ & Verma et al. [60] \\
\hline $\begin{array}{l}\text { Whole plant } \\
\text { extract }\end{array}$ & Apiol, Phytol, n-Hexadeconoic acid, E-2-Tetradecen-1-ol, Stigmasterol, Campesterol, and Sitosterol & $\begin{array}{l}\text { Narayanamoorthi et al. } \\
\text { [61] }\end{array}$ \\
\hline Essential oil & $\gamma$-gurjunene, 1,10-di-epicubenol, (E)-caryophyllene, dillapiole, carotol, trans- $\beta$-guaiene & de Oliveira et al. [62] \\
\hline Essential oil & Phytol, $\alpha$-terpineol, $\beta$-caryophyllene, d-limonene, linalool & Okoh et al. [63] \\
\hline
\end{tabular}

Ragasa et al. [39] isolated dill-apiol, aurantiamide acetate and pachypophyllin from leaf extract of $P$. pellucida and elucidated their structure by NMR studies. Pellucidin A, a novel dimeric ArC2 compound, along with dill-apiol has been isolated by Bayma et al. [64] from the aerial parts of P. pellucida. The structure of pellucidin A was established by spectral analyses. The study carried out by Xu et al. [65] revealed isolation of compounds such as secolignans, tetrahydrofuran lignans, highly methoxylated dihydronaphthalenone, peperomins, sesamin and isoswertisin from the whole plant of $P$. pellucida. Khan et al. [66] recovered a xanthone glycoside from leaves of $P$. pellucida and characterized the compound as Patuloside A (3- $\beta$-D-glucopyranosyloxy-1,5,6trihydroxy-9H-xanthene-9-one) by performing various chromatographic and spectral analyses. Leena and Annam [67] isolated a flavone glycoside from whole plant of $P$. pellucida and characterized the compound as vitexin by chromatographic and spectral analyses. The study carried out by Hartati et al. [41] identified compounds viz. stigmasterol, analogue of pheophytin and $\beta$-sitosterol-D-glucopyranoside in the solvent extract of $P$. pellucida. Susilawati et al. [68] isolated a compound namely 8,9-dimethoxy ellagic acid from the ethyl acetate fraction of leaf of $P$. pellucida by column chromatography and the structure was elucidated by chromatographic and spectral analyses. A compound by name $3{ }^{\prime}, 4^{\prime}$, dihydroxy-3-5-dimethoxy flavone-7-0- $\beta$-rhamnose was isolated from ethyl acetate fraction of crude methanolic extract of aerial parts of $P$. pellucida and the structure was elucidated by the spectral data [43]. The study carried out by Ahmad et al. [69] revealed a total alkaloid content of $29.59 \mathrm{mg} / \mathrm{g}$ piperine in the dichloromethane fraction of plant material. Fig. 2 shows the structure of some of the compounds identified in the plant.

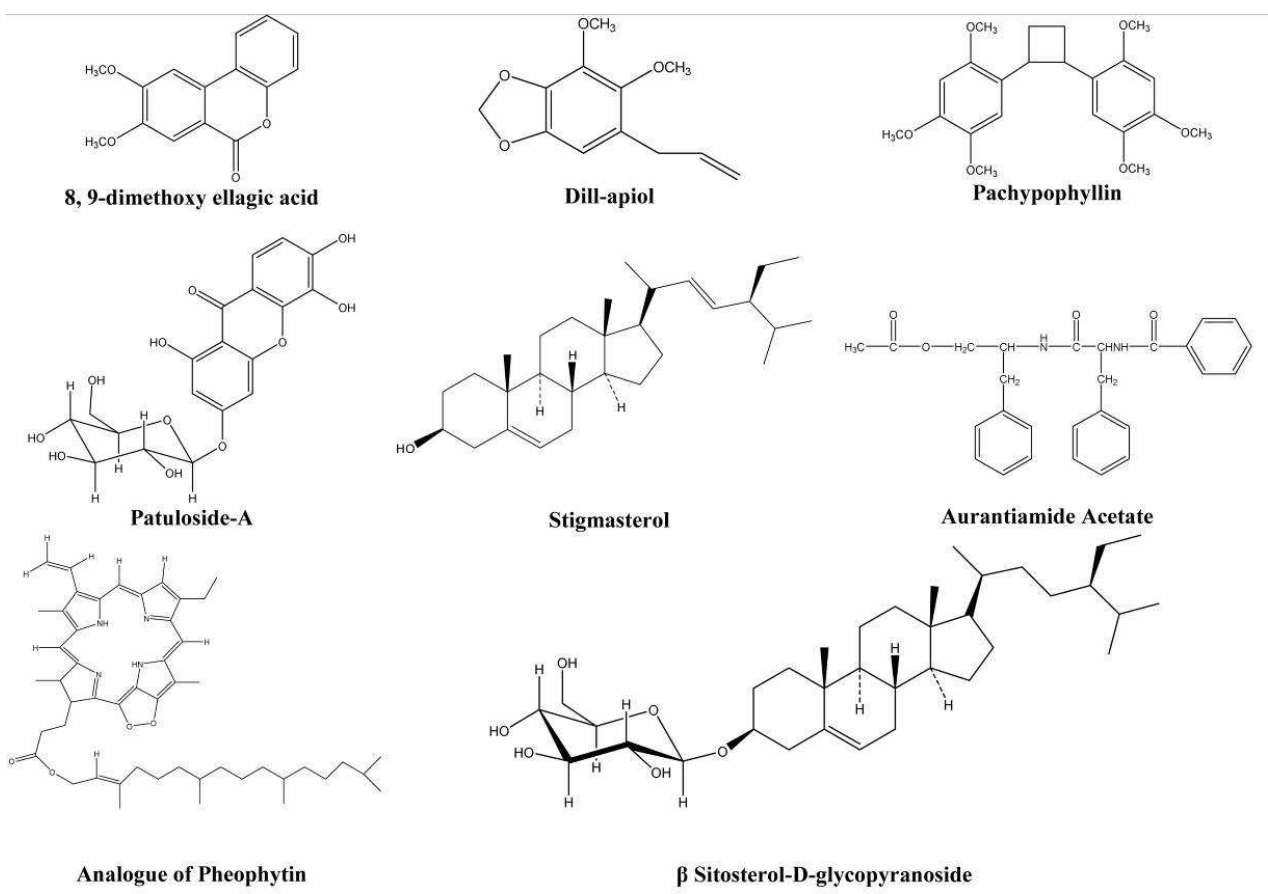

Fig. 2: Structures of some compounds identified in P. pellucida $[39,41,66,68]$

\section{Pharmacological activities of $P$. Pellucida}

Many studies have been carried out to investigate pharmacological properties of $P$. pellucida. The plant is reported to exhibit several bioactivities such as hypotensive, immunostimulatory, antioxidant, antimicrobial, analgesic, anti-inflammatory, fracture healing, gastroprotective and antidiabetic activity.

Concise information on pharmacological activities of extracts and purified compounds of P. pellucida is discussed below. 


\section{Hypotensive activity}

Nwokocha et al. [70] evaluated hypotensive activity of aqueous extract from whole plant of $P$. pellucida in rat model. Intravenous administration of extract showed a dose dependent reduction in systolic and diastolic blood pressure, heart rate and mean arterial pressure. It was shown in the study that the extract induces bradycardia and hypotension in normotensive rats via mechanisms that are nitric oxide dependent. The study carried out by Fasola and Adeboye [71] also revealed antihypertensive activity of $P$. pellucida in normotensive rats. Intravenous administration of methanol extract resulted in marked decrease in mean arterial blood pressure and heart rate.

\section{Neuropharmacological activity}

The study carried out by Khan et al. [72] indicated that the petroleum ether and ethyl acetate fractions of ethanol extract of leaves of $P$. pellucida possess central nervous system depressant effect as the fractions were shown to possess dose dependent effects on duration of diazepam-induced sleep, nikethamide-induced toxicity, light-dark test and force swimming test.

\section{Immunostimulatory activity}

In a study, Lee et al. [73] revealed the potential of leaf extract of $P$. pellucida (mixed with fish pellets) as an immunostimulator in controlling motile aeromonad septicemia caused by Aermomonas hydrophila in Oreochromis spp. (red hybrid tilapia). It was observed that the mortality rate was considerably lesser in fishes that were fed with diet which was mixed with leaf extract.

\section{Antimutagenicity activity}

Ragasa et al. [39] evaluated antimutagenic activity of dill-apiol and pachypophyllin isolated from leaf extract of $P$. pellucida by micronucleus test. The compounds were not effective as the study did not indicated significant reduction in micronucleated polychromatic erythrocytes induced by mitomycin C.

\section{Anti-angiogenic activity}

The study carried out by Camposano et al. [74] revealed antiangiogenic activity of methanol extract of $P$. pellucida in terms of inhibition of angiogenesis in chorioallantoic membrane assay. The extract was shown to inhibit angiogenesis with an activity of $26 \%$.

\section{Fracture healing activity}

Ngueguim et al. [75] evaluated the potential of ethanol extract of $P$. pellucida on bone regeneration following bone and marrow injury in rats, and determined the mode of action. The extract dosedependently induced bone regeneration at the fracture site and significantly increased mineral deposition. The extract was also found to improve microarchitecture of the regenerating bone. It was shown that the extract accelerates fracture repair via stimulatory effects on osteoblast differentiation and mineralization. Recently, Florence $e t$ al. [76] revealed the potential of aqueous extract of $P$. pellucida to accelerate fracture healing in Wistar rats. Radiological tests revealed a dose dependent formation of callus at the level of the fracture gap and was evidenced by formation of a highly dense and compact fibrocartilagenous callus.

\section{Antiulcerogenic/gastroprotective activity}

Roslida and Aini [77] evaluated gastroprotective (antiulcerogenic) activity of ethanolic extract of aerial parts of $P$. pellucida in indomethacin and necrotizing agent induced models in rats. The result revealed that the extract at all doses produced significant inhibition of gastric mucosal damage induced by necrotizing agents and indomethacin. Rojas-Martínez et al. [78] determined gastroprotective activity of solvent extracts and Dillapiole from $P$. pellucida. Dichloromethane extract of leaf and stem displayed marked gastroprotective activity in rats with ethanol induced gastric ulcer. Dillapiole also exhibited marked gastroprotection.

\section{Analgesic activity}

Aziba et al. [79] determined analgesic activity of methanol extract of aerial parts of $P$. pellucida by acetic acid induced writhing in mice. It was observed that oral administration of extract $(70-210 \mathrm{mg} / \mathrm{kg})$ exhibited a significant analgesic activity in mice. Arrigoni-Blank et al. [80] evaluated analgesic activity of aqueous extract prepared from aerial parts of $P$. pellucida by abdominal writhing and hot plate tests. The extract displayed significant analgesic activity at extract concentration of $400 \mathrm{mg} / \mathrm{kg}$ and $100 \mathrm{mg} / \mathrm{kg}$ in abdominal writhing and hot plate test respectively. The study carried out by Sheikh et al. [54] revealed analgesic potential of ethyl acetate extract of whole plant by acetic acid-induce writhing in mice.

\section{Antipyretic activity}

The study carried out by Khan et al. [81] revealed the antipyretic potential of petroleum ether and ethyl acetate soluble fractions of ethanol extract of leaves of $P$. pellucida in boiled milk induced pyrexia in albino rabbits. Administration of solvent fractions at a dose of $80 \mathrm{mg} / \mathrm{kg}$ body weight showed a significant reduction in elevated body temperature in albino rabbits.

\section{Anti-inflammatory activity}

Arrigoni-Blank et al. [82] evaluated anti-inflammatory activity of aqueous extract of leaves of $P$. pellucida by carrageenan induced paw edema test in rats. It was observed that the extract obtained from plants in all seasons displayed antiedematogenic activity with significant activity observed in phenophases of winter and spring. Arrigoni-Blank et al. [80] evaluated anti-inflammatory activity of aqueous extract prepared from aerial parts of $P$. pellucida by paw edema induced by carrageenan and arachidonic acid. It was observed that oral administration of 200 and $400 \mathrm{mg} / \mathrm{kg}$ of the extract showed an anti-inflammatory activity in the carrageenan test, which was based on interference with synthesis of prostaglandin, as confirmed by the arachidonic acid test. The study carried out by Mutee et al. [83] indicates the anti-inflammatory potential of petroleum ether, chloroform and methanol extract of $P$. pellucida in carrageenan induced rat paw edema. Among extracts, petroleum ether extract displayed significant activity when compared to chloroform and methanol extracts.

\section{Antimicrobial activity}

Ragasa et al. [39] isolated dill-apiol and pachypophyllin from leaf extract of $P$. pellucida and determined their antimicrobial activity. These compounds were selectively effective against Trichophyton mentagrophytes while other test microbes were not affected. In a study, Khan and Omoloso [84] screened antimicrobial activity of crude methanolic extract and petrol, dichloromethane, ethyl acetate and butanol fractions of methanolic extract of $P$. pellucida. Crude extract and fractions displayed broad spectrum antibacterial activity. Butanol fraction of crude extract was more active. Patuloside A isolated from leaves of $P$. pellucida was shown to display concentration dependent inhibition of Gram positive and Gram negative bacteria. Patuloside A showed weak activity against Aspergillus flavus and Candida albicans while A. niger and Rhizopus oryzae were unaffected [66]. Further details on the antimicrobial potential of $P$. pellucida described by other researchers are shown in table 4.

\section{Antidiabetic activity}

Humzah et al. [93] showed that diet containing P. pellucida $(10 \%$ and $20 \%$ ) possess antidiabetic effect in alloxan-induced diabetes in rats. A considerable reduction in the blood glucose level was observed in the study. The levels of aspartate transaminase (AST), alanine transaminase (ALT) and alkaline phosphate (ALP) were lesser in rats fed with diet containing $P$. pellucida. Moreover, the concentration of total cholesterol, triglycerides (TG), high-density lipoprotein (HDL) and low-density lipoprotein (LDL) content were also lesser in rats fed with diet containing P. pellucida. The levels of superoxide dismutase (SOD), catalase and glutathione were also increased. Sheikh et al. [54] evaluated antidiabetic activity of ethyl acetate extract of whole plant of P. pellucida in alloxan-induced diabetic mice. A significant hypoglycemic effect was observed in mice administered with extract. 8,9-dimethoxy ellagic acid, isolated from leaf extract of $P$. pellucida, was evaluated for antidiabetic activity by alloxan-induced hyperglycemia in mice [68]. The compound was shown to exhibit $33.74 \%$ blood glucose lowering in normoglycemic model at $100 \mathrm{mg} / \mathrm{kg}$ dose. 
Table 4: Antimicrobial potential of $P$. pellucida

\begin{tabular}{|c|c|c|c|}
\hline Extract & Part & Activity against & References \\
\hline $\begin{array}{l}\text { Aqueous and ethanol } \\
\text { extract }\end{array}$ & Leaf & Gram negative bacteria & $\begin{array}{l}\text { Akinnibosun et al. } \\
\text { [85] }\end{array}$ \\
\hline Methanol extract & $\begin{array}{l}\text { Whole } \\
\text { plant }\end{array}$ & Bacillus subtilis and Candida albicans & Wiart et al. [86] \\
\hline Methanol extract & Leaf & Gram positive and Gram negative bacteria & Wei et al. [58] \\
\hline $\begin{array}{l}\text { Methanol extract, solvent } \\
\text { fractions }\end{array}$ & Leaf & $\begin{array}{l}\text { Gram positive and Gram negative bacteria; Fungi namely Aspergillus, } \\
\text { Rhizopus, Candida and Penicillium }\end{array}$ & Oloyede et al. [87] \\
\hline Solvent extracts & Leaf & $\begin{array}{l}\text { Pseudomonas aeruginosa, Salmonella typhii and Shigella dysenteriae and } \\
\text { Aspergillus niger }\end{array}$ & Ibibia et al. [52] \\
\hline $\begin{array}{l}\text { Aqueous and organic } \\
\text { extracts }\end{array}$ & Leaf & Gram positive and Gram negative bacteria & Ojo et al. [47] \\
\hline Alcohol extract & & Gram positive and Gram negative bacteria & Mensah et al. [88] \\
\hline Essential oil & Leaf & Fusarium moniliforme, Rhizopus stolonifer & Francois et al. [59] \\
\hline Ethanol extract & Leaf & Gram positive and Gram negative bacteria & $\begin{array}{l}\text { Igwe and Mgbemena } \\
\text { [89] }\end{array}$ \\
\hline Ethanol & Leaf & Shigella dysenteriae & Uddin et al. [90] \\
\hline Solvent extracts & Leaf & Gram positive and Gram negative bacteria & Zubair et al. [91] \\
\hline $\begin{array}{l}\text { Aqueous and methanol } \\
\text { extract }\end{array}$ & Aerial parts & Aeromonas hydrophila, Enterobacter cloacae, Streptococcus agalactiae & $\begin{array}{l}\text { Raina and Hassan } \\
\text { [56] }\end{array}$ \\
\hline Solvent extracts & $\begin{array}{l}\text { Whole } \\
\text { plant }\end{array}$ & Gram positive and Gram negative bacteria & Idris et al. [50] \\
\hline Essential oils & $\begin{array}{l}\text { Leaf and } \\
\text { stem }\end{array}$ & Gram positive, Gram negative bacteria, Mycobacterium smegmatis & Okoh et al. [63] \\
\hline Ethanol extract & Leaf & Candida albicans & Hastuti et al. [92] \\
\hline
\end{tabular}

\section{Acaricidal activity}

In a study, de Oliveira et al. [62] evaluated the activity of the essential oils from leaf and stem against Tetranychus urticae. It was observed that the stem oil was fourfold more toxic than the leaf oil however the activity of essential oils was lesser than eugenol, the positive control.

\section{Anticancer/cytotoxic activity}

Peperomin E, isolated from whole plant of P. pellucida, was found to exhibit cytotoxicity against cell lines viz. HL-60, MCF-7 and HeLa cell lines [65]. Khan et al. [66] determined cytotoxic activity of Patuloside A, isolated from leaves of $P$. pellucida, against brine shrimp nauplii. The compound exhibited cytotoxicity with an $\mathrm{LC}_{50}$ value of $18.24 \mu \mathrm{g} / \mathrm{ml}$ and the activity observed was lesser when compared to standard drug. Wei et al. [58] determined cytotoxic potential of methanolic extract of $P$. pellucida leaf against MCF-7 cell line by 3-(4,5-dimethylthiazol-2-yl)-2,5-diphenyltetrazolium bromide (MTT) assay. The extract displayed concentration dependent cytotoxicity with an $\mathrm{IC}_{50}$ value of $10.4 \pm 0.06 \mu \mathrm{g} / \mathrm{ml}$. Oloyede et al. [87] screened cytotoxicity of crude methanol extract and fractions such as hexane, ethyl acetate, butanol and aqueous fractions of leaves of $P$. pellucida by brine shrimp lethality assay. Crude extract, hexane and ethyl acetate fractions were shown to be effective while butanol and aqueous fractions were not effective in causing mortality of brine shrimp larvae.

\section{Antioxidant activity}

Mutee et al. [83] determined antiradical activity of chloroform, petroleum ether and methanol extract of $P$. pellucida by 2,2-diphenyl1-picrylhydrazyl (DPPH) assay. Methanol extract was shown to display marked scavenging of free radicals when compared to other extracts. Wei et al. [58] screened methanolic extract of P. pellucida leaf for radical scavenging potential by DPPH assay. The extract was shown to display concentration dependent scavenging of radicals but the activity observed was considerably lesser than that of quercetin. Oloyede et al. [87] determined antioxidant potential of crude methanolic extract and hexane, ethyl acetate, butanol and aqueous fractions of leaves of $P$. pellucida by DPPH scavenging, hydrogen peroxide scavenging and ferric thiocyanate method. Extract and fractions were shown to exhibit marked activity in all methods. The study carried out by Beltran-Benjamin et al. [94] revealed an increase in the levels of antioxidant enzymes viz. superoxide dismutase and catalase on administration of crude methanolic extract of $P$. pellucida in rats. Phongtongpasuk and Poadang [95] evaluated antioxidant potential of butanol, ethyl acetate and methanol extracts of P. pellucida obtained by maceration and reflux method. Extracts obtained by reflux method displayed marked DPPH scavenging activity and reducing power. Phenolic content was also higher in extracts obtained by reflux method. The study carried out by Okoh et al. [63] showed the antioxidant potential of essential oil of leaf and stem of $P$. pellucida. The essential oils exhibited concentration dependent scavenging of DPPH, 2,2'-azino-bis(3-ethylbenzothiazoline-6-sulphonic acid (ABTS) and nitric oxide radicals.

\section{Enzyme inhibitory activity}

In a study, Ong et al. [96] evaluated porcine pancreatic lipase inhibitory activity of methanolic extract of leaves of $P$. pellucida and observed lesser potential of leaf extract to cause inhibition of lipase activity when compared to standard. Kurniawan et al. [43] isolated a compound by name $3^{\prime}, 4^{\prime}$, dihydroxy-3-5-dimethoxy flavone-7-0- $\beta$ rhamnose from aerial parts of $P$. pellucida and evaluated its inhibitory activity against Angiotensin converting enzyme (ACE). The compound was found to inhibit ACE dose dependently with an IC 50 value of $7.72 \mu \mathrm{g} / \mathrm{ml}$. Ethyl acetate fraction was more potent than the compound. The study carried out by Parawansah et al. [97] showed the potential of ethanol extract of leaves of P. pellucida to inhibit the activity of xanthine oxidase. Extract was shown to exhibit inhibition of xanthine oxidase with an $\mathrm{IC}_{50}$ value of $19.5 \mathrm{ppm}$.

\section{Antisickling activity}

Abere and Okpalaonyagu [51] evaluated antisickling activity of leaves of $P$. pellucida on the inhibition of sodium metabisulphiteinduced sickling of the HbSS red blood cells. Leaf extract was found to significantly inhibit sickling of red cells with maximum inhibition of sickling (57.5\%) at $500 \mathrm{mg} / \mathrm{ml}$ of the extract.

\section{Anti-ostioporesis activity}

The study carried out by Putri et al. [98] revealed the potential of ethanol extract of $P$. pellucida $(100 \mathrm{mg} / \mathrm{kg}$ body weight $[\mathrm{b} . \mathrm{w}])$ to prevent osteoporosis in ovariectomized (OVX)-induced osteoporotic rats. At $100 \mathrm{mg} / \mathrm{kg}$ concentration, the extract treated rats showed improvement on three-dimensional image of the trabecular bone compared with the OVX-control group. Also, the trabecular cavity formation in $100 \mathrm{mg} / \mathrm{kg}$ extract-treated group was minimal.

\section{Fibrinolytic activity}

The study of Ebenezer et al. [99] showed a weaker fibrinolytic activity of $P$. pellucida extract. The in vitro clot lysis activity was 
considerably lesser when compared to extracts from other plants. In another study, Zubair et al. [91] revealed the potential of ethyl acetate, hexane, chloroform and aqueous soluble fractions of $P$. pellucida to cause lysis of clot indicating thrombolytic activity. Marked activity was displayed by ethyl acetate soluble fraction.

\section{Antidiarrhoeal activity}

The ethanolic extract of $P$. pellucida leaves was evaluated for antidiarrhoeal activity in castor oil-induced diarrhoea in mice. The extract was shown to display concentration dependent antidiarrhoeal activity [91].

\section{Hair growth promotion activity}

The study carried out by Kanedi et al. [100] revealed the potential of crude extract of $P$. pellucida in a topical gel formulation to promote hair growth in rabbits dose dependently. The mean hair length increased on increasing the concentration of extract in the gel.

\section{Proximate and nutritive attributes of $P$. Pellucida}

Egwuche et al. [55] evaluated nutritive attributes of P. pellucida leaves from Nigeria. The leaves were shown to contain carbohydrates $(38.97 \%)$, proteins $(7.68 \%)$, crude fibre $(22.35 \%)$ and fat $(1.08 \%)$. The leaves were also shown to contain appreciable quantity of calcium, magnesium, potassium and sodium. The study carried out by Ooi et al. [101] revealed the nutritive composition of P. pellucida from Malaysia. The plant was shown to contain an appreciable quantity of carbohydrates (about $45 \%$ ) and proteins (about 10\%) however the lipid content was low (about 3\%). The plant is also shown to possess considerable quantity of potassium, calcium, iron and sodium.

\section{CONCLUSIONS}

The plant P. pellucida is a well-known medicinal plant being used ethnomedicinally for treatment of various diseases worldwide. In vitro and in vivo studies have shown many pharmacological activities of the plant which supports the traditional use of the plant. Literatures have shown the potential of isolated compounds to exhibit bioactivities such as antimicrobial, anticancer, gastroprotective and antidiabetic activities. The presence of phytochemicals such as alkaloids, flavonoids, saponins, tannins and glycosides in the plant could be responsible for the pharmacological activities of the plant. The plant P. pellucida appears to be suitable for developing drugs that can be used to treat several diseases or disorders. Utilization of the plant in suitable form can be beneficial in terms of promotion of health and disease therapy.

\section{SOURCES OF SUPPORT}

\section{None}

\section{AUTHORS CONTRIBUTIONS}

Both the authors namely Dr. Prashith Kekuda T. R and Dr. Raghavendra H. L were involved equally in literature survey, framing contents, writing draft paper and finalizing the review paper.

\section{CONFLICTS OF INTERESTS}

Authors declared that there are no potential conflicts of interest

\section{REFERENCES}

1. Fabricant DS, Farnsworth NR. The value of plants used in traditional medicine for drug discovery. Environ Health Perspect 2001;109 Suppl 1:69-75.

2. Pérez M, Boffill MA, Morón FJ, Sueiro ML, Marrero E, Betancourt E. Ethnopharmacological and preclinical study of diuretic activity in medicinal and food plants used by Cuban population. Emirates J Food Agric 2011;23:214-21.

3. Ayyanar M. Traditional herbal medicines for primary healthcare among indigenous people in Tamil Nadu, India. J Homeopathy Ayurvedic Med 2013;2:140.

4. Leonti M, Casu L. Traditional medicines and globalization: current and future perspectives in ethnopharmacology. Front Pharmacol 2013;4:92.
5. Hong L, Guo Z, Huang K, Wei S, Liu B, Meng S, et al. Ethnobotanical study on medicinal plants used by Maonan people in China. J Ethnobiol Ethnomed 2015;11:32.

6. Raghavendra HL, Kekuda PTR, Pushpavathi D, Shilpa M, Petkar $\mathrm{T}$, Siddiqua A. Antimicrobial, radical scavenging, and insecticidal activity of leaf and flower extracts of Couroupita guianensis Aubl. Int J Green Pharm 2017;11:171-9.

7. Fyson PF. The flora of the nilgiri and pulney hill-tops. Vol. I. Bishen Singh Mahendra Pal Singh, Dehra Dun and Periodical Experts, Delhi; 1974. p. 345.

8. Bhat GK. Flora of South Kanara. Akriti Prints, Mangalore; 2014. p. 43.

9. Vergara Rodriguez D, Mathieu G, Samain M, Armenta Montero S, Kromer T. Diversity, distribution, and conservation status of Peperomia (Piperaceae) in the state of veracruz, Mexico. Trop Conservation Sci 2017;10:1-28.

10. Melo A, Guimaraes EF, Alves M. Synopsis of the genus Peperomia ruiz and pav. (Piperaceae) in roraima state, Brazil. Hoehnea 2016;43:119-34.

11. Termote C, Van Damme P, Dhed'a Djailo B. Eating from the wild: Turumbu indigenous knowledge on noncultivated edible plants, Tshopo District, DR Congo. Ecol Food Nutr 2010;49:173-207.

12. Coe FG, Anderson GJ. Ethnobotany of the sumu (Ulwa) of southeastern Nicaragua and comparisons with Miskitu plant lore. Econ Bot 1999;53:363-86.

13. Whitney CW, Min VS, Giang LH, Can VV, Barber K, Lanh TT. Conservation and ethnobotanical knowledge of a Hmong community in long lan, Luang Prabang, Lao People's Democratic Republic. Ethnobot Res Appl 2014;12:643-58.

14. Hadi S, Bremner JB. Initial studies on alkaloids from Lombok medicinal plants. Molecules 2001;6:117-29.

15. Das NJ, Saikia SP, Sarkar S, Devi K. Medicinal plants of NorthKamrup district of Assam used in primary healthcare system. Indian J Tradit Know 2006;5:489-93.

16. Lans CA. Ethnomedicines used in trinidad and tobago for urinary problems and diabetes mellitus. J Ethnobiol Ethnomed 2006;2:45.

17. Sonibare MA, Moody JO, Adesanya EO. Use of medicinal plants for the treatment of measles in Nigeria. J Ethnopharmacol 2009;122:268-72.

18. Santos MRA, Lima MR, Oliveira CLLG. Medicinal plants used in Rondônia, Western Amazon, Brazil. Rev Bras Plant Med 2014;16 Suppl 1:707-20.

19. Chukwuma EC, Soladoye MO, Feyisola RT. Traditional medicine and the future of medicinal plants in Nigeria. J Med Plants Studies 2015;3:23-9.

20. Olowa L, Demayo CG. Ethnobotanical uses of medicinal plants among the muslim maranaos in Iligan city, Mindanao, Philippines. Adv Environ Biol 2015;9:204-15.

21. Chithra M, Geetha SP. Plant based remedies for the treatment of rheumatism among six tribal communities in Malappuram district, Kerala. Int J Bot Studies 2016;1:47-54.

22. Kalita GJ, Rout S, Mishra RK, Sarma P. Traditionally used medicinal plants of bajali subdivision, barpeta district, Assam. J Med Plants Studies 2015;3:8-17.

23. Koch M, Kehop DA, Kinminja B, Sabak M, Wavimbukie G, Barrows KM, et al. An ethnobotanical survey of medicinal plants used in the East Sepik province of Papua New Guinea. J Ethnobiol Ethnomed 2015;11:79.

24. Waty DR, Saputri FC, Munim A. Secondary metabolites screening and acute toxicity test of Peperomia pellucida (L.) Kunth methanolic extracts. Int J PharmTech Res 2017;10:31-8.

25. Rahmatullah M, Mollik MAH, Paul AK, Jahan R, Khatun MA, Seraj S, et al. A comparative analysis of medicinal plants used to treat gastrointestinal disorders in two sub-districts of Greater Khulna division, Bangladesh. Adv Nat Appl Sci 2010;4:22-8.

26. Mollik MAF, Hossan MS, Paul AK, Taufiq-Ur-Rahman M, Jahan $\mathrm{R}$, Rahmatullah M. A comparative analysis of medicinal plants used by folk medicinal healers in three districts of Bangladesh and inquiry as to mode of selection of medicinal plants. Ethnobot Res Appl 2010;8:195-218.

27. Buragohain J. Ethnomedicinal plants used by the ethnic communities of Tinsukia district of Assam, India. Recent Res Sci Technol 2011;3:31-42. 
28. Bharali P, Sharma CL, Singh B, Sharma M. Ethnobotanical studies of spice and condiment plants used by some communities of Assam. Int J Adv Sci Res 2017;3:1-11.

29. Bordoloi R, Kashyap K, Das A. Ethno-medicinal study on the traditional herbal knowledge of the Tiwa tribe of Morigaon district of Assam, India. Asian J Sci Technol 2017;8:5484-9.

30. Bose D. An ethno-medicobotanical investigation among Rava tribe of Jalpaiguri district. NBU J Plant Sci 2011;5:61-5.

31. Rahmatullah M, Ayman U, Akter F, Sarker M, Sifa R, Sarker B, et al. Medicinal formulations of a Kanda tribal healer-A tribe on the verge of disappearance in Bangladesh. Afr J Tradit Complementary Altern Med 2013;10:213-22.

32. Ruysschaert S, Van Andel T, Van de Putte K, Van Dammea P. Bathe the baby to make it strong and healthy: plant use and child care among saramaccan maroons in suriname. J Ethnopharmacol 2009;121:148-70.

33. Vandebroek I, Balick MJ, Ososki A, Kronenberg F, Yukes J, Wade $\mathrm{C}$, et al. The importance of botellas and other plant mixtures in dominican traditional medicine. J Ethnopharmacol 2010; 128:20-41.

34. Uzodimma DE. Medico-ethnobotanical inventory of Ogii, Okigwe Imo state, South Eastern Nigeria-I. Global Adv Res J Med Plants 2013;2:30-44.

35. Gogoi B, Zaman K. Phytochemical constituents of some medicinal plant species used in recipe during 'Bohag Bihu' in Assam. J Pharmacogn Phytochem 2013;2:30-40.

36. Clement YN, Baksh Comeau YS, Seaforth CE. An ethnobotanical survey of medicinal plants in Trinidad. J Ethnobiol Ethnomed 2015;11:67.

37. Das PR, Islam MT, Jahan R, Rahmatullah M. Ethnomedicinal plants used by the Nag clan of the Rai Ghatual tribe of Moulvibazar district, Bangladesh. Ancient Sci Life 2013;32:217-21.

38. Bora R, Das AK. An inventory of ethnomedicinal plants among the rabha tribe residing nearby chandubi beel of kamrup district (Assam). Int J Innovative Res Sci Technol 2015;1:126-9.

39. Ragasa CY, Dumato M, Rideout JA. Antifungal compounds from Peperomia pellucida. ACGC Chem Res Commun 1998;7:54-61.

40. Sasidharan S, Chen Y, Saravanan D, Sundram KM, Latha YL. Extraction, isolation and characterization of bioactive compounds from plants' extracts. Afr J Tradit Complementary Altern Med 2011;8:1-10.

41. Hartati S, Angelina M, Dewiyanti ID, Meiliawati L. Isolation and characterization compounds from hexane and ethyl acetate fractions of Peperomia pellucida L. J Trop Life Sci 2015;5:117-22.

42. Papitha R, Ravi L, Selvaraj CI. Phytochemical studies and GC-MS analysis of Spermadictyon suaveolens Roxb. Int J Pharm Pharm Sci 2017;9:143-9.

43. Kurniawan A, Saputri FC, Rissyelly, Ahmad I, Munim A. Isolation of angiotensin converting enzyme (ACE) inhibitory activity quercetin from Peperomia pellucida. Int J PharmTech Res 2016;9:115-21.

44. Biswas SM. Optimized analytical techniques for extraction and separation of bioactive compounds from diverse plant types. Biochem Anal Biochem 2017;6:313.

45. Ingle KP, Deshmukh AG, Padole DA, Dudhare MS, Moharil MP, Khelurkar VC. Phytochemicals: extraction methods, identification and detection of bioactive compounds from plant extracts. J Pharmacogn Phytochem 2017;6:32-6.

46. Gini TG, Jothi JG. Preliminary phytochemical screening of whole plant extracts of Peperomia pellucida (Linn.) HBK (Piperaceae) and Marsilea quadrifolia Linn. (Marsileaceae). Int J Pharmacogn Phytochem Res 2013;5;200-14.

47. Ojo 00, Ajayi SS, Owolabi LO. Phytochemical screening, antinutrient composition, proximate analyses and the antimicrobial activities of the aqueous and organic extracts of bark of Rauvolfia vomitoria and leaves of Peperomia pellucida. Int Res J Biochem Bioinformatics 2012;2:127-34.

48. Majumder P, Kumar AKV. Establishment of quality parameters and pharmacognostic evaluation of leaves of Peperomia pellucida (L.) HBK. Int J Pharm Pharm Sci 2011;3:375-8.

49. Omotayo FO, Borokini TI. Comparative phytochemical and ethnomedicinal survey of selected medicinal plants in Nigeria. Sci Res Essays 2012;7:989-99.
50. Idris 00, Olatunji BP, Madufor P. In vitro antibacterial activity of the extracts of Peperomia pellucida (L). Br Microbiol Res J 2016;11:1-7.

51. Abere TA, Okpalaonyagu SO. Pharmacognostic evaluation and antisickling activity of the leaves of Peperomia pellucida (L.) HBK (Piperaceae). Afr J Pharm Pharmacol 2015;9:561-6.

52. Ibibia ET. Phytochemical and antimicrobial analyses of extracts of Peperomia pellucida (L). J Pharm Res 2012;5:2934-7.

53. Majumder P. Phytochemical, pharmacognostical and physicochemical standardization of Peperomia pellucida (L.) HBK. stem. Int J Comprehensive Pharm 2011;8:1-4.

54. Sheikh H, Sikder S, Paul SK, Hasan RAM, Rahaman MM, Kundu SP. Hypoglycemic, anti-inflammatory and analgesic activity of Peperomia pellucida (L.) HBK (Piperaceae). Int J Pharm Sci Res 2013;4:458-63.

55. Egwuche RU, Odetola AA, Erukainure OL. Preliminary investigation into the chemical properties of Peperomia pellucida L. Res J Phytochem 2011;5:48-53.

56. Raina MS, Hassan MD. Screening of phytochemical properties and antimicrobial activity of Malaysian medicinal plants against aquatic bacteria. Malays J Microbiol 2016;12:284-90.

57. Da Silva MHL, Zoghbi MDGB, Andrade EHA, Maia JGS. The essential oils of Peperomia pellucida Kunth and P. circinnata Link var. circinnata. Flavour Fragrance J 1999;14:312-4.

58. Wei LS, Wee W, Siong JYF, Syamsumir DF. Characterization of anticancer, antimicrobial, antioxidant properties and chemical compositions of Peperomia pellucida leaf extract. Acta Med Iranica 2011;49:670-4.

59. Francois T, Michel JDP, Vyry WNA, Fabrice FB, Lambert SM, Henri AZP, et al. Composition and antifungal properties of essential oils from five plants growing in the mountainous area of the West Cameroon. J Essent Oil-Bear Plants 2013;16:679-88.

60. Verma RS, Padalia RC, Goswami P, Chauhan A. Essential oil composition of Peperomia pellucida (L.) Kunth from India. J Essent Oil Res 2015;27:89-95.

61. Narayanamoorthi V, Vasantha K, Rency RC, Maruthasalam A. GC MS determination of bioactive components of Peperomia pellucida (L.) Kunth. Biosci Discovery 2015;6:83-8.

62. de Oliveira JCS, da Camara CAG, Neves RCS, Botelho PS. Chemical composition and acaricidal activity of essential oils from Peperomia pellucida Kunth against Tetranychus urticae. Rev Virtual Quim 2017;9:1-9.

63. Okoh SO, Iweriebor BC, Okoh 00, Okoh AI. Bioactive constituents, radical scavenging, and antibacterial properties of the leaves and stem essential oils from Peperomia pellucida (L.) kunth. Pharmacogn Mag 2017;13 Suppl S3:392-400.

64. Bayma JD, Arruda MS, Müller AH, Arruda AC, Canto WC. A dimeric ArC2 compound from Peperomia pellucida. Phytochemistry 2000;55:779-82.

65. Xu S, Li N, Ning MM, Zhou CH, Yang QR, Wang MW. Bioactive compounds from Peperomia pellucida. J Nat Prod 2006;69:247-50.

66. Khan A, Rahman M, Islam MS. Isolation and bioactivity of a xanthone glycoside from Peperomia pellucida. Life Sci Med Res 2010; LSMR-1:1-10.

67. Leena PK, Annam C. Isolation and characterization of flavone glycoside vitexin from Peperomia pellucida Linn. J Drug Delivery Ther 2013;3:91-2.

68. Susilawati Y, Nugraha R, Krishnan J, Muhtadi A, Sutardjo S, Supratman U. A new antidiabetic compound 8,9-dimethoxy ellagic acid from sasaladaan (Peperomia pellucida L. Kunth). Res J Pharm Biol Chem Sci 2017;8(1S):269-74.

69. Ahmad I, Rissyelly, Kurniawan A, Munim A. Screening of extraction method for alkaloid enrichment of Peperomia pellucida (L.) Kunth. Asian J Pharm Clin Res 2017;10:214-9.

70. Nwokocha CR, Owu DU, Kinlocke K, Murray J, Delgoda R, Thaxter $\mathrm{K}$, et al. Possible mechanism of action of the hypotensive effect of Peperomia pellucida and interactions between human cytochrome P450 enzymes. Med Aromat Plants 2012;1:105.

71. Fasola TR, Adeboye JO. Anti-hypertensive potentials of Peperomia pellucida (L.) HBK in anaesthetized normotensive rats. Adv Life Sci Technol 2015;29:1-4.

72. Khan A, Rahman M, Islam MS. Neuropharmacological effects of Peperomia pellucida leaves in mice. DARU 2008;16:35-40. 
73. Lee SW, Sim KY, Wendy W, Zulhisyam AK. Peperomia pellucida leaf extract as immunostimulator in controlling motile aeromonad septicemia due to Aeromonas hydrophila in red hybrid tilapia, Oreochromis spp. farming. Vet World 2016;9:231-4.

74. Camposano JE, Torre DGLT, Laxamana JG, Larcia LLH. Screening for the anti-angiogenic activity of selected Philippine medicinal plants using chorioallantoic membrane assay. Mahidol Univ J Pharm Sci 2016;43:173-82.

75. Ngueguim FT, Khan MP, Donfack JH, Tewari D, Dimo T, Kamtchouing $\mathrm{P}$, et al. Ethanol extract of Peperomia pellucida (Piperaceae) promotes fracture healing by an anabolic effect on osteoblasts. J Ethnopharmacol 2013;148:62-8.

76. Florence NT, Huguette STS, Hubert DJ, Raceline GK, Desire DDP, Pierre K, et al. Aqueous extract of Peperomia pellucida (L.) HBK accelerates fracture healing in Wistar rats. BMC Complementary Altern Med 2017;17:188.

77. Roslida AH, Aini NZ. Evaluation of gastroprotective effects of the ethanolic extract of Peperomia pellucida (L) Kunth. Pharmacologyonline 2009;2:676-86.

78. Rojas Martinez R, Arrieta J, Cruz Antonio L, Arrieta Baez D, Velazquez Mendez AM, Sanchez Mendoza ME. Dillapiole, isolated from Peperomia pellucida, shows gastroprotector activity against ethanol-induced gastric lesions in wistar rats. Molecules 2013;18:11327-37.

79. Aziba PI, Adedeji A, Ekor M, Adeyemi O. Analgesic activity of Peperomia pellucida aerial parts in mice. Fitoterapia 2001;72:57-8.

80. Arrigoni Blank FM, Dmitrieva EG, Franzotti EM, Antoniolli AR, Andrade MR, Marchioro M. Anti-inflammatory and analgesic activity of Peperomia pellucida (L.) HBK (Piperaceae). J Ethnopharmacol 2004;91:215-8.

81. Khan A, Rahman M, Islam S. Antipyretic activity of Peperomia pellucida leaves in rabbit. Turk J Biol 2008;32:37-41.

82. Arrigoni Blank MF, Oliveira RLB, Mendes SS, Silva PA, Antoniolli AR, Vilar JC, et al. Seed germination, phenology, and antiedematogenic activity of Peperomia pellucida (L.) H. B. K. BMC Pharmacol 2002;2:12.

83. Mutee AF, Salhimi SM, Yam MF, Lim CP, Abdullah GZ, Ameer OZ, et al. In vivo anti-inflammatory and in vitro antioxidant activities of Peperomia pellucida. Int J Pharmcol 2010;6:686-90.

84. Khan MR, Omoloso AD. Antibacterial activity of Hygrophila stricta and Peperomia pellucida. Fitoterapia 2002;73:251-4.

85. Akinnibosun HA, Akinnibosun FI, German BE. Antibacterial activity of aqueous and ethanolic leaf extracts of Peperomia pellucida (L.) H. B. and K. (Piperaceae) on three gram-negative bacteria isolates. Sci World J 2008;3:33-6.

86. Wiart C, Mogana S, Khalifah S, Mahan M, Ismail S, Buckle M, et al. Antimicrobial screening of plants used for traditional medicine in the state of Perak, Peninsular Malaysia. Fitoterapia 2004;75:68-73.

87. Oloyede GK, Onocha PA, Olaniran BB. Phytochemical, toxicity, antimicrobial and antioxidant screening of leaf extracts of
Peperomia pellucida from Nigeria. Adv Environ Biol 2011;5:3700-9.

88. Mensah JK, Ihenyen JO, Okhiure MO. Nutritional, phytochemical and antimicrobial properties of two wild aromatic vegetables from Edo State. J Nat Prod Plant Resour 2013;3:8-14.

89. Igwe OU, Mgbemena NM. Chemical investigation and antibacterial activity of the leaves of Peperomia pellucida L. HBK (Piperaceae). Asian J Chem Pharm Res 2014;2:78-86.

90. Uddin SB, Sultana R, Faruque O. Antibacterial activity of some selected medicinal plants used by the Rakhaing community of Cox's Bazar district of Bangladesh. Academia J Microbiol Res 2014;2:21-7.

91. Zubair KL, Samiya JJ, Jalal U, Mostafizur R. In vitro investigation of antdiarrhoeal, antimicrobial and thrombolytic activities of aerial parts of Peperomia pellucida. Pharmacologyonline 2015;3:5-13.

92. Hastuti US, Ummah YPI, Khasanah HN. Antifungal activity of Piper aduncum and Peperomia pellucida leaf ethanol extract against Candida albicans. AIP Conference Proceedings 2017;1844:020006-1-020006-4. Doi.org/10.1063/1.4983417.

93. Humzah RU, Odetola AA, Erukainure OL, Oyagbemi AA. Peperomia pellucida in diets modulates hyperglyceamia, oxidative stress and dyslipidemia in diabetic rats. J Acute Disease 2012;1:135-40.

94. Beltran Benjamin KS, Co EL, Gaspi SAD, Matibag JLR, Su GLS. Enzyme activity and histopathology of rat liver treated with crude methanolic extract of Pepperomia pellucida (L.) HBK. J Biol Sci 2013;13:183-95.

95. Phongtongpasuk S, Poadang S. Extraction of antioxidants from Peperomia pellucida L. Kunth. Thammasat Int J Sci Technol 2014;19:38-43.

96. Ong S, Van SP, Lai H, Rao NK. In vitro lipase inhibitory effect of thirty two selected plants in Malaysia. Asian J Pharm Clin Res 2014;7:19-24.

97. Parawansah, Nuralifah, Alam G, Natzir R. Inhibition of xanthine oxidase activity by ethanolic extract of Peperomia pellucida L., Acacypha indica L. and Momordica charantia L. Indonesian Biomed J 2016;8:161-6.

98. Putri CA, Kartika GAA, Adnyana K. Preventive effect of Peperomia pellucida (L.) Kunth herbs on ovariectomy-induced osteoporotic rats. J Chin Pharm Sci 2016;25:546-51.

99. Ebenezer OA, Kenneth E, Monday BB, Hilda MO. Fibrinolytic activity of some Nigerian medicinal plants. J Pharm Pharmacol 2014;2:177-84.

100. Kanedi M, Lande ML, Nurcahyani N, Anggraeni IR, Yulianty. Hair-growth promoting activity of plant extracts of suruhan (Peperomia pellucida) in rabbits. IOSR J Pharm Biol Sci 2017;12:18-23.

101. Ooi D, Iqbal S, Ismail M. Proximate composition, nutritional attributes and mineral composition of Peperomia pellucida L. (Ketumpangan Air) grown in Malaysia. Molecules 2012;17:11139-45. 